\title{
TARĖJŲ INSTITUTO LIETUVOS RESPUBLIKOS TEISMŲ SISTEMOJE MODELIO PAIEŠKOS TEORINIAI ASPEKTAI
}

\author{
Darijus Beinoravičius, Milda Vainiutė \\ Mykolo Romerio universitetas
}

\begin{abstract}
Anotacija
Valdžios struktūra ir jos veikla demokratinejje valstybèje turi būti grindžiama valdžių atskyrimo principu. Taip siekiama užtikrinti individualias teises ir laisves bei padèti visuomenei užkirsti kelią valdžios savivalei. Kiekviena valdžios galia ịgyvendinama per tam tikras institucijas: parlamentą, atstovaujantị tautai ir leidžiantị ịstatymus bei vykdantị kitas Konstitucijoje numatytas funkcijas; Vyriausybę, kuri ịgyvendina parlamento priimtus ịstatymus; teismus, kurie vykdo teisingumą. Jei valstybẻ negarantuoja teisingumo ịgyvendinimo, visos kalbos apie demokratiją, teisètumą, pilietinę visuomenę, žmogaus teises ir laisves lieka deklaratyvios. Tik nepriklausomos ir savarankiškos teisminès institucijos gali tinkamai atlikti savo pareigas - vykdyti teisingumą, užtikrinti Konstitucijoje, ịstatymuose ir kituose teisès aktuose ịtvirtintų nuostatų ịgyvendinimą, garantuoti teisès viršenybę, ginti žmogaus teises ir laisves. Natūraliai kyla klausimas, ar teisingumą vykdantys teismai užtikrina šių principų ịgyvendinimą, ar pilietis, kreipęsis ị teismą, kad apgintų savo pažeistas teises, gali būti tikras, jog teismas ginčą išspręs nešališkai ir atkurs pažeistas teises. Straipsnio autoriai nagrinejja tokią svarbią temą kaip pasitikejjimas teismais, aptaria, kokiais būdais ir priemonèmis galima pasiekti didesnio pasitikejjimo šalies valdžia. Keliamas klausimas, ar būtų veiksminga Lietuvoje steigti teismų tarejų institutą. Autoriai formuluoja išvadą, kad Lietuva yra viena iš nedaugelio demokratinių šalių, neturinčių prisiekusiųjų teismų ar tarèjų institucijos, kurios ịkūrimas padètų mažinti korupciją teisinejje sistemoje. Be to, būtų žengtas žingsnis siekiant padidinti visuomenès pasitikèjimą teismais. Pagrindinè išvada - būtina skatinti diskusijas apie nuosaikų tarẻjų institucijos modelị. Autoriai mano, kad toks koncepcijos modelis neformuotų intervencijos ị 1992 m. Lietuvos Respublikos Konstituciją ir teisinę sistemą, o papildytų esamą praktiką bei Konstitucijoje išreikštą siekį stiprinti valdžios institucijų ryšį su visuomene. Tokio siekio plètojimo modelis būtų prasmingas.

PAGRINDINIAI ŽODŽIAI: demokratija, teismas, teisingumas.
\end{abstract}

\begin{abstract}
Government organization and activities in a democratic state must be based on the principle of separation of powers. The essence of this principle is to ensure individual rights and freedoms and to help the society prevent government arbitrariness. Each power is implemented through its institutions: Parliament, representing the Nation, legislate the laws and perform other functions provided in the Constitution, the Government implement the laws legislated by Parliament and courts execute justice. If the state does not ensure the implementation of justice, all the talk of democracy, the rule of law, civil society, human rights and freedoms are declarative. Only being independent and autonomous judicial authorities can properly fulfill their function - to execute justice, to ensure implementation of law, expressed in the Constitution, laws and other legal norms, to guarantee the rule of law, to protect human rights and freedoms. Inevitably, the question must be raised whether the courts executing justice ensure these constitutional principles good enough and whether the citizen applying to the court to protect his violated rights can be sure that the court will resolve the dispute impartially and restore his violated rights. Authors of the article examine such an important topic as confidence in the courts, discuss the possible ways and means to achieve that the state government would be more trusted. In the article authors raise a question whether it would be effective to establish associate judges' institute in Lithuania. The authors conclude that Lithuania is one of the few democratic
\end{abstract}


countries having no jury or associate judges institution and that its establishment would help reduce corruption in the legal system. Also it would be a step to increase public confidence in the judiciary. The main conclusion is that discussions about moderate model of associate judges' institution shall be encouraged. The authors believe that such a concept model would not form intervention in the Constitution of the Republic of Lithuania of 1992 and legal framework, but would complement the practice and the commitment to strengthen the relation between the public authorities and society, which is expressed in the Constitution. The model of such aspiration development really makes sense and would be very necessary.

KEY WORDS: democracy, court, justice.

DOI: http://dx.doi.org/10.15181/tbb.v79i2.1775

\section{Ivadas}

Demokratinèje valstybėje valdžios organizacija ir veikla turi būti grindžiama valdžių padalijimo principu, kurio esmè - užtikrinti asmens teises ir laisves, padèti visuomenei išvengti valdžios savivalès. Valdžių padalijimas, asmens teisès ir laisvės yra pagrindiniai konstitucionalizmo elementai. Kiekviena valdžia įgyvendinama per jos institucijas: Seimas, atstovaudamas tautai, leidžia ịstatymus ir atlieka kitas Konstitucijoje numatytas funkcijas, Vyriausybė igyvendina Seimo leidžiamus įstatymus, teismai vykdo teisingumą.

Jeigu valstybejje neužtikrintas teisingumo igyvendinimas, visos kalbos apie demokratiją, teisinę valstybę, pilietinès visuomenès kūrimą, žmogaus teisių ir laisvių gynimą yra deklaratyvios. Tik būdama nepriklausoma ir savarankiška teisminè valdžia gali tinkamai ịgyvendinti savo funkciją - vykdyti teisingumą, užtikrinti Konstitucijoje, ịstatymuose ir kituose teisès normų aktuose išreikštos teisès igyvendinimą, garantuoti teisès viršenybę, apsaugoti žmogaus teises bei laisves. Neišvengiamai turi būti keliamas klausimas, ar teismai, vykdydami teisingumą, pakankamai užtikrina šiuos konstitucinius principus, ar pilietis, norėdamas apginti savo pažeistas teises, kreipdamasis ị teismą gali būti tikras, kad šis ginčą išspręs nešališkai ir atkurs jo pažeistas teises.

\section{Teismų funkcija - vykdyti teisingumą}

Teismai ir jų sistema yra vienas iš valstybès atributų. Dabartiniu metu teisminès valdžios buvimas ir jos atskyrimas nuo kitų valstybès valdžios šakų laikomas būtinu demokratinès ir teisinès valstybès požymiu. Demokratinèse valstybėse, kurios pripažịsta valdžiu padalijimo principą, teismai laikomi tautos ịsteigta savarankiška valstybès valdžios šaka (Birmontienè, 2012).

Remiantis 1992 m. Lietuvos Respublikos Konstitucija, valstybės valdžia organizuota ir igyvendinama laikantis valdžių padalijimo principo. Teisminè valdžia - 
viena iš trijų valdžių, vykdanti specifinę teisingumo funkciją, kurios negali vykdyti jokia kita valstybės institucija ar pareigūnas. Valdžių padalijimo principas, teisingumo vykdymo funkcijos reikšmingumas suponuoja visavertės teisminės valdžios poreikị. Tik visavertis teismas gali tinkamai vykdyti teisingumą, taigi teisminės valdžios visavertiškumas - teisingo teismo prielaida, nes tik tokio teismo reikia visuomenei. Teisminès valdžios visavertiškumo doktrina suformuota daugelyje Lietuvos Respublikos Konstitucinio Teismo nutarimų. Ji laikytina tinkamo teismams pavestos misijos atlikimo garantija.

Pagrindinio Lietuvos Respublikos teisinès sistemos akto - Konstitucijos 109 straipsnyje įtvirtinta, kad teisingumą Lietuvos Respublikoje vykdo tik teismai, kurie, vykdydami teisingumą, yra nepriklausomi, be to, teisèjai, nagrinèdami bylas, klauso tik ịstatymo. Teisejų ir teismų nepriklausomumas yra vienas fundamentaliausių teisinès demokratinès valstybès bruožų. Jo laikomasi visose demokratinėse valstybėse, ir, kaip rodo istorinè patirtis, šio principo atsisakymas yra imanentinis totalitarinio ir autoritarinio režimo bruožas.

Taigi teismas yra viena iš valstybès valdžios sudètinių dalių, kuris turi išimtinę kompetenciją vykdyti teisingumą. Teismo padètis tarp kitų valstybės valdžių atskleidžia valstybės demokratijos išsivystymo lygị, tai, kiek ịtvirtintos valstybejje žmogaus teisių ir laisvių garantijos ir kokiu laipsniu jos ginamos. Teismo funkcija - vykdyti teisingumą - neabejotinas valstybės pamatas. Teismas sprendžia visuomenejje kylančius teisinius ginčus, užtikrina teisės normų laikymąsi, jis veikia jau po to, kai pažeistos asmens teisès bei laisvès, remdamasis byloje esančia bei papildomai surinkta medžiaga, konstatuoja, buvo ar nebuvo pažeistos asmens teisès ir teisèti interesai, padarytas nusikaltimas. Be to, teismams tenka svarbus uždavinys - aiškinti ịstatymus ir teisès principus, juos taikyti vykdant teisingumą. Teismams priskiriama ir konstitucinè norminių teisès aktų kontrolè. Kadangi teismai yra valstybės valdžios dalis, galima daryti prielaidą, kad jie dalyvauja ịgyvendinant visas pagrindines valstybės funkcijas, pavyzdžiui, palaiko ekonominę sąrangą, saugo fundamentalius nuosavybès principus, sprendžia socialinius konfliktus, esant būtinybei sankcionuoja represinị valstybès veiklos pobūdị.

Pagrindinės žmogaus teisès ir laisvès įtvirtintos Lietuvos Respublikos Konstitucijos II skirsnyje - tai žmogaus teisè ị gyvybę, žmogaus laisvès ir jo asmens, jo privataus gyvenimo, nuosavybès ir būsto neliečiamumas, teisẻ turèti ịsitikinimus ir juos laisvai reikšti, minties, tikèjimo ir sąžinès laisvè, visų asmenų lygybė prieš ịstatymą ir teismą, asmens teisé į teisminę gynybą ir kt.

Asmens teisès ị teisminę gynybą principas ịtvirtintas Konstitucijos 30 straipsnio 1 dalyje. Konstituciné asmens teisè ị teisminę gynybą ir kai kurie kiti principai rodo, kad valstybė ne tik deklaruoja asmens teises, bet ir ịsipareigoja jas ginti, neatsižvelgdama ị tai, kas yra pažeidèjas, - kitas asmuo ar pati valstybè. Lietuvos 
Respublikos Konstitucinis Teismas 2006 m. sausio 16 d. nutarime konstatavo, jog šis principas reiškia, kad Lietuvoje, kaip teisinèje valstybeje, kiekvienam turi būti užtikrinta galimybė savo teises ginti teisme tiek nuo kitu asmenų, tiek nuo neteisètų valstybės institucijų ar pareigūnų veiksmų; teisę ginti savo teises ir laisves teisme turi kiekvienas asmuo, manantis, kad jo teisès ar laisvès pažeistos; teisès kreiptis į teismą igyvendinimą lemia paties asmens suvokimas, kad jo teisès ar laisvès pažeidžiamos; asmens pažeistos teisès, inter alia ịgytosios teisès ir teisèti interesai teisme turi būti ginami nepaisant to, ar jie yra tiesiogiai ịtvirtinti Konstitucijoje. Konstitucinė asmens teisẻ kreiptis ị teismą, aiškinama kitų Konstitucijos nuostatų kontekste, suponuoja ir tai, kad ịstatymu turi būti nustatytas toks teisinis reguliavimas, kad bendrosios kompetencijos ar specializuoto pirmosios instancijos teismo baigiamajj aktą būtų galima apskųsti bent vienos aukštesnès instancijos teismui. Teisè kreiptis i teismą yra absoliuti, todèl ši asmens konstitucinè teisė negali būti dirbtinai suvaržoma, be to, negali būti nepagrịstai pasunkinamas jos igyvendinimas.

Šią konstitucinę teisę asmuo turi teisę igyvendinti tiesiogiai, remdamasis Konstitucija ( 6 str. 2 d.). Asmens teisè ị teisminę gynybą neatsiejama ir nuo kitų Konstitucijos normų bei principų: lygiateisiškumo, teisès į žalos atlyginimą, tinkamą teisinị procesą ir kt. (Abramavičius, 2009).

Žmonių santykius reguliuoja religijos, moralès ir teisès normos. Visuomeniniai santykiai bus tik tada visaverčiai ir darnūs, kai visų šių normų bus laikomasi, o pažeidus tam tikros teisès normas, nedelsiant užtikrinamas jų laikymasis. Todèl galima teigti, kad teismai užima ypatingą vietą ne tik valstybės valdžių sistemoje, bet ir visuomenès sąmonėje. Nepaisant visuomenèje vyraujančių nuotaikų ir politikų replikų teismų atžvilgiu, žmonių akyse teismų sistema yra socialinės apsaugos mechanizmas, vienintelè viltis ginant jų pažeistas teises ir laisves. Veikdamas nepaisydamas jokios galimos įtakos, teismas turi tapti socialinių ir ekonominių santykių garantija.

Teismas yra vienas iš socialinès darnos įrankių. Teigiama (Baublys, 2005), kad teisès paskirtis visada siejama su tam tikros socialinès darnos siekiu, kurio rezultatą galima ịvardyti teisingumo ịgyvendinimu. Todèl viena iš socialinès darnos egzistavimo sąlygų - visuomenès žinojimas, kad bet kuriuo atveju bus užtikrintos piliečio teisès ir laisvès, kad bet koks kilęs ginčas bus išspręstas teisingai ir nešališkai. Toks visuomenès sąmoningas žinojimas galimas tik pasitikint teismais. Asmenims galbūt ne taip svarbu, kokia valstybẻje egzistuoja institucinė teismų sistema, kaip organizuojamas teismų darbas. Kiekvienas asmuo suinteresuotas, kad jo byla būtų nagrinejjama per įmanomai trumpiausią laiką, vadovaujantis lygybès principu, viešumo sąlygomis nepriklausomo ir nešališko teismo. Toks noras yra visiškai suprantamas. 


\section{Pasitikėjimo teismais klausimas}

Lietuvai atkūrus nepriklausomą demokratinę valstybę, teismų sistemos reforma vykdyta intensyviai, todèl neretai skubotai. Teismų įstatymai buvo vieni dažniausiai keičiamų teisès aktų. Per dvidešimt penkis nepriklausomybės metus igyvendinti esminiai teismų sistemos pertvarkymai. Visų šių reformų tikslas - sukurti tokią teismų sistemą, kuri pirmiausia užtikrintų kiekvieno visuomenès nario teisių ir teisètų interesų apsaugą, garantuotų tinkamą jo teisių gynybą ne tik kitų individų, bet ir valstybės atžvilgiu.

Demokratinèje teisinejje valstybejje teismai, atlikdami socialinị teisminès valdžios vaidmenį, vykdo teisingumą, privalo užtikrinti Konstitucijoje, įstatymuose ir kituose teisès aktuose įtvirtintų normų laikymąsi, garantuoti teisès viršenybę, apsaugoti žmogaus teises bei laisves. Čia vartojama pasitikẻjimo teismais sąvoka gali būti apibrèžiama kaip žmonių tikèjimas sąžiningu ir atsakingu teisingumo ịgyvendinimu, žmogaus teisių ir laisvių apsaugos šaltinis.

Iš sovietmečio paveldèjome piliečių nepasitikejjimo valstybès institucijomis problemą, kuri gilèjo visą nepriklausomybès laikotarpị. Teigiama, kad pasitikèjimas valstybės institucijomis yra vienas iš demokratinès santvarkos veiksmingumo rodiklių, todèl žemas pasitikejjimo lygmuo rodo problemų demokratinèje visuomenèje buvimą (Burnytè, 2013). Valstybèje ir visuomenèje paplitęs nihilizmas giliai įleido šaknis ir sunkiai užleidžia vietą pasitikejimui valstybès valdžios institucijomis bei pilietinès visuomenès galiomis. Ne išimtis ir teismai. Pasitikejjimui teismais įtaką daro ir bendras visuomenès socialinis pasitikejjimo lygis. Tenka konstatuoti, kad pasitikejjimo teismu lygis Lietuvoje žemas (Beinoravičius, 2013).

Pasitikejjimo teismais aktualumą suponuoja nuo atkurtos nepriklausomos Lietuvos iki dabar visuomenėje vyraujančios nuotaikos. Visuomenès pasitikejjimas teismais visų pirma prasideda teismo veiklos suvokimu, kuris neimmanomas be atitinkamos informacijos apie teismus. Ne viena pastaruoju metu surengtų apklausų Lietuvoje rodo menką pasitikẻjimą teismais. Pasitikejjimas teismine valdžia Lietuvoje pradètas sistemingai tirti nuo $1993 \mathrm{~m}$. (Pirmieji apklausos rezultatai buvo žemi, „Baltijos tyrimų“ duomenimis, 1993 m. Lietuvos nacionaline sistema pasitikejjo tik 30 proc. apklaustujų.) Per pastaraji penkmetị ižvelgiamas menkas visuomenès pasitikèjimas teismais. (Pavyzdžiui, visuomenès ir rinkimų tyrimo centro „Vilmorus“ 2016 m. sausio 14-22 d. atlikta apklausa rodo, kad 25,1 proc. asmenu teismais pasitikèjo, 27,4 proc. - nepasitikèjo.) Toks visuomenès požiūris ị teismus ir teisėjus pastebimas per visus atkurtos nepriklausomos Lietuvos metus. Dažnas asmuo su teismais tiesiogiai nesusiduria. Natūraliai kyla klausimas, ar visuomenei pakanka informacijos apie teismų veiklą, kurią šiandien Lietuvoje dažniausia pa- 
teikia žiniasklaida, ar ši informacija yra objektyvi ir nepamina teisminės valdžios principų?

İsišaknijusio socialinio nepasitikèjimo sąlygomis visuomenès nariai ịtariai vertina teismų pastangas vykdyti teisingumą, todèl neigiamos žinios apie teismų veiklą gali sukelti ilgalaikius neigiamus socialinius padarinius, kaip pasitikejimo teismais silpnejjimą ir teisinio nihilizmo įsitvirtinimą. Ši problema aktuali šiandienos vartotojiškai visuomenei, kai yra pakitusios vertybès, pilietinès visuomenés idealai, pavienis individas ar juridinis asmuo iškeliamas aukščiau už bendruomenès viešuosius interesus, pelnas tapo gyvenimo tikslu ir prasme. Šiame kontekste klostosi pavojinga elito politinès galios koncentracija.

Kyla klausimas, ar teismų, priskirtų prie kitų valstybès valdžios institucijų, reitingavimas yra pagrịstas ir nepažeidžia teismų nepriklausomumo principo? Savo veiklos specifika teismai labai skiriasi nuo kitų valstybės institucijų. Pavyzdžiui, nagrinėdamas bylas teismas niekada negali patenkinti visų byloje dalyvaujančių šalių lūkesčių. Priẻmus vienai iš ginčo šalių nepriimtiną sprendimą, dažnai daroma apibendrinta išvada, kad teismas prièmé neteisingą sprendimą. Tokioje situacijoje asmeniui, kuris neturi pakankamai teisinių žinių ir nesuvokia teismo veiklos specifikos, sunku objektyviai suvokti priimto sprendimo pagrịstumą. Todèl galima teigti, kad „Vilmorus“ ar panašių institucijų apklausos duomenis galima vertinti dvejopai: 1) nepasitikinčiujų teismais skaičius atitinka teoriškai tiketiną; 2) pasitikinčiujų teismais skaičius teoriniu požiūriu yra per mažas ir jis išreiškia pasitikèjimo / nepasitikèjimo teismais esmę. Atsižvelgiant ị pasitikinčiujų teismais skaičių, vertinama pasitikejjimo teismais būklè. Kita vertus, apklausos rezultatų negalima ignoruoti, nes teismo, kaip ir kitų valstybès valdžios institucijų, paskirtis - tarnauti žmonėms.

Problema, kas ir kaip formuoja visuomenès nuomonę apie teismų darbą bei teisèjų kompetenciją. Žiniasklaida nuolat pateikia ịvairių vertinimų apie teismų priimtus sprendimus, apie teismų sprendimus, priimtus visuomenès dėmesio sulaukusiose bylose, nuomonę reiškia ir politikos atstovai. Neigiami vieši teismų veiklos vertinimai daro įtaką visuomenès, ypač asmenų, kurie niekada nebuvo tiesiogiai susidūrę su teismais, nuomonei ir taip mažina pasitikẻjimą teismais, galų gale pačia valstybe, nes teismai yra sudètinè valstybės valdžios dalis. Nurodomas dar vienas pasitikèjimą teismais lemiantis veiksnys - teisèjo asmeninès savybès, profesionalumas ir profesinè elgsena, kitaip tariant, teisèjų etika.

Mokslinèje literatūroje autoriai dažniausia išskiria teismų veiklai būdingus veiksnius. Reikètų paminèti, kad pasitikèjimui teismais ịtaką gali daryti ir teismų vidinis administravimas bei darbo organizavimas, nes tai lemia teismo proceso trukmę. Kaip teisingos ir pagrịstos nuomonès apie teismus formavimo pagrindą reikia įvardyti nuoseklų teisinès sąmonès formavimą. İtakos apie teismų darbą turi ir bylų nagrinëjimo procesinè tvarka. 
Dažna problema - teismas susijęs su nemažomis išlaidomis, todèl pasinaudoti šia teise kartais sudètinga. Tai didelè našta nepasiturintiems asmenims, todèl galima teigti, kad suvaržoma asmens teisė ginti savo pažeistas teises. Ilgą laiką Lietuvos piliečiams nebuvo garantuotos tinkamos sąlygos ginti savo pažeistas teises ar ịstatymų saugomus interesus. Tik 2001 m. sausio 1 d. priẻmus Lietuvos Respublikos valstybės garantuojamos teisinès pagalbos įstatymą Lietuvos Respublikos piliečiams ir Lietuvoje nuolat gyvenantiems užsienio piliečiams bei asmenims be pilietybès, dèl turtinès padèties negalintiems tinkamai ginti savo teisių ir ịstatymų saugomų interesų, garantuota teisinè pagalba. Atitinkamos pataisos Teismų ịstatyme padarytos tik $2002 \mathrm{~m}$. sausio $24 \mathrm{~d}$., patvirtinus naują Teismų ịstatymo redakciją, kuri ịsigaliojo nuo 2002 m. gegužès 1 d. (Bilevičiūtè, 2014).

Aptariant pasitikejimo teismais svarbą, reikia suprasti, kad piliečiai, priimdami Konstituciją ir suteikdami teismui išskirtinę funkciją - teisingumo vykdymą, turi teisę iš teismo ir teisejjų reikalauti sąžiningo, kvalifikuoto darbo bei nešališkai priimamų sprendimų garantijų. Pasitikèjimas teismais būtinas, siekiant, kad veiksmingai funkcionuotų demokratinè teisinè valstybè, būtų kuriama pilietiné visuomené, kuri būtų garantuota, jog jos pažeistas teises ir laisves visada apgins nepriklausomas ir nešališkas teismas.

Pasitikejimo teismais problema susijusi su teismo veiklos viešumo stoka. Prieš analizuojant teisminès valdžios atvirumo piliečiams svarbą, kyla klausimas, kiek ir kaip turi pasireikšti teisminès valdžios atvirumas? Reikia paaiškinti, kad teismų sistemos atvirumas neturi varžyti teismų ir teisejjų nepriklausomumo principo, negali daryti ịtakos teisèjų priimamiems sprendimams. Reikalavimas valdžiai būti atvirai ịtvirtintas Konstitucijos 5 straipsnyje, kuris skelbia, kad valdžios įstaigos tarnauja žmonėms, o 33 straipsniu ịtvirtinta piliečių teisẻ kritikuoti valdžios ịstaigu ar pareigūnų darbą, apskųsti jų sprendimus. Šis klausimas svarstomas gana plačiai, nes Konstitucijos 114 straipsnyje skelbiama, kad draudžiamas bet koks kišimasis ị teisejjo ar teismo veiklą. Teisminès valdžios atvirumas pasireiškia per skaidrų teisminès valdžios tarnavimą visuomenei, galimybę piliečiams gauti visą būtiną informaciją apie žmogaus teises ir laisves bei apginti pažeistas teises.

\section{Visuomenès atstovai (tarẻjai) teisme}

Aptariant teismų ir teisèjų nepriklausomumo principą, reikia pabrěžti, kad jis negali būti absoliutus, nes šio principo suabsoliutinimas sukeltų absurdišką situaciją, reikštų šios valdžios visišką uždarumą ir izoliavimąsi, o tai grèstų teismų bei teisèjų savivaliavimu. Kad taip neatsitiktų, sudaromos sąlygos visuomenès atstovams dalyvauti teisejjų skyrimo, vertinimo, kontrolès procese. Pavyzdžiui, Teismų ịstatymo $55^{1}$ straipsnyje nustatyta, kad Pretendentų ị teisèjus atrankos komisiją 
sudaro Lietuvos Respublikos Prezidentas ir septyni nariai, iš kuriu keturi - visuomenès atstovai. Vadovaujantis Teismų ịstatymo 54 straipsnio 1 dalimi, 85 straipsnio 2 dalimi bei $91^{3}$ straipsnio 4 dalimi, visuomenès atstovai dalyvauja ir Pretendentų ị teisèjus egzamino, Teisèjų etikos ir drausmès bei Nuolatinès teisejų veiklos vertinimo komisijų darbe. Pažymètina, kad visuomenès atstovų institutas padeda ịvertinti būsimų ar esamų teisèjų ne tiek teisines žinias, kiek asmenines savybes bei moralines vertybes, būtinas kvalifikuotai teisėjo veiklai, todèl svarbu užtikrinti veiksmingą visuomenès atstovų dalyvavimą teisèjų skyrimo, vertinimo, kontrolès procese.

Kaip dar vieną žingsnị skatinant visuomenès atstovų dalyvavimą veikloje, kuri nesusijusi su teisingumo vykdymu, galima pateikti Teismų įstatymo 103 ir 104 straipsniuose nustatytą reglamentavimą. Minèto įstatymo 103 straipsnyje nustatyta, kad teismo pirmininkas, igyvendindamas jam priskirtas vidinio administravimo funkcijas, gali sudaryti teismo administracinès veiklos ar su teisingumo vykdymu nesusijusios teisèjo veiklos tyrimo komisiją, ị kurią gali būti įtraukti kitų teismų teisejai ar tarnautojai, taip pat kitų institucijų, įstaigų specialistai, mokslininkai, visuomenès atstovai. Tuo tarpu remiantis 104 straipsnio nuostatomis teismų administracinès veiklos priežiūrą atliekantys subjektai (apylinkių teismų atitinkamo apygardos teismo pirmininkas; apygardų administracinių teismų Vyriausiojo administracinio teismo pirmininkas; apygardų teismų - Apeliacinio teismo pirmininkas; Apeliacinio teismo - Aukščiausiojo Teismo pirmininkas; visų teismų - Teisëjų taryba), igyvendindami teismų administracinès veiklos priežiūros funkcijas, gali atlikti teismo administracinès veiklos ar su teisingumo vykdymu nesusijusios teisejo veiklos tyrimus. Šiam tikslui gali būti sudaryta tyrimo komisija, ị kurią gali būti ịtraukti kelių teismų teisèjai, taip pat kitų institucijų, įstaigų specialistai, mokslininkai, visuomenès atstovai.

Šiandieninėje Lietuvoje, kaip ir daugelyje šiuolaikinių demokratiškų šalių, teisẻjai savo ịgaliojimus gauna ne per demokratiškų rinkimų procedūras, bet skyrimo būdu. Pasitikèjimas teismine valdžia taip pat netikrinamas rinkèjų balsavimu. Teigtina, kad skaidrus teisminès valdžios tarnavimas visuomenei prasideda nuo teisejjų korpuso sudarymo, kuris formuojamas profesiniu pagrindu. Tai konstatavo Lietuvos Respublikos Konstitucinis Teismas, kurio nutarimuose teigiama, kad teisminè valdžia formuojama ne politiniu, bet profesiniu pagrindu. Teisejjas pagal jo atliekamas pareigas negali būti priskirtas prie valstybės tarnautojų. Iš jo negali būti reikalaujama vykdyti kokios nors politikos krypties. Teismų praktiką formuoja tik patys teismai, taikydami teisès normas. Žmogaus teises ir laisves teisèjas užtikrina tuo, kad vykdo teisingumą, remdamasis Konstitucija ir ịstatymais (Lietuvos Respublikos Konstitucinio Teismo 1999 m. gruodžio 21 d. nutarimas). 
Teisininkai ir mokslininkai nuolat diskutuoja dėl prisiekusiųjų ar tarejjų instituto. Vis dèlto dauguma teisininkų šių institutų veiksmingumą ir tikslingumą vertina atsargiai. Vieni jị traktuoja kaip vieną skaidraus teisminès valdžios tarnavimo priemonių, teisminès valdžios viešumo užtikrinimo būdų, taip mažinant abejones dèl teismų priimamų sprendimų objektyvumo bei didinant pasitikejjimą teismais, kiti mano, kad mūsų visuomenė dar nepribrendo tokiems pokyčiams, tuo labiau pati visuomenè neišreiškia didelio poreikio. Tiesa, tam Seimas turètų pakeisti Konstituciją. Taigi pati svarbiausia tarejų instituto ịsteigimo problema sietina su Konstitucija, kurios IX skirsnyje „Teismas“, kuris nustato Lietuvos Respublikos teismu sąrangą bei veiklos principus, įtvirtinta imperatyvi nuostata, jog teisejjai skiriami (112 str.), numatant galimybę steigti tik specializuotus teismus. Apie teismų tarejų instituciją ar bent jau jos steigimo perspektyvą čia nekalbama. Norint įtvirtinti ši institutą, neabejotinai reikètų keisti Konstituciją.

Reikia pasakyti, kad tokių bandymų jau buvo ne vienas. Antai 2007 m. gegužès 9 d. Seimo narių grupé pateikè Lietuvos Respublikos Konstitucijos 109, 110 ir 112 straipsnių pakeitimo ịstatymo projektą, kurio aiškinamajame rašte nurodomas esminis tikslas - teismų sistemos priartinimas prie visuomenès ir užtikrinimas, kad teismai atliktų Konstitucijos 5 straipsnyje postuluotą pareigą tarnauti žmonėms. Ši tikslą padètų pasiekti dviejų uždavinių ịgyvendinimas: teisèjų karjeros skaidrumo didinimas ir visuomenės atstovų dalyvavimas vykdant teisingumą. Kiek vẻliau, t. y. 2007 m. liepos 4 d., pateiktas patobulintas šio ịstatymo projekto variantas - Lietuvos Respublikos Konstitucijos 109, 110, 112 ir 114 straipsnių pakeitimo ịstatymo projektas.

Prie šio klausimo sugrižta ir vèliau. Štai 2015 m. birželio 16 d. pateiktas Lietuvos Respublikos Konstitucijos 109, 110, 112, 113 ir 114 straipsnių pakeitimo istatymas. Šio projekto aiškinamajame rašte nurodoma, kad Teisès instituto atlikta viešosios nuomonės apklausa rodo, jog visuomenė palaiko teismų tarẻjų įtvirtinimą Lietuvos teismų sistemoje: 25,5 procentai apklaustujų mano, jog tarejjų institutas reikalingas, 17,6 - nereikalingas ir 29,9 apklaustujų neturi nuomonės. Rašte nurodytas ir šio projekto tikslas - Konstitucijoje ịtvirtinti visuomenès atstovus teismuose - teismų tarejjus. Projekto uždaviniai: mažinti nepasitikẻjimą teismais; sudaryti visuomenei galimybes dalyvauti ịgyvendinant teisingumą; skatinti bylu nagrinejjimo objektyvumą; bylas nagrinèti bešališkai ir įvairiapusiškiau; efektyviau ginti žmogaus teises.

Naujausias postūmis šioje srityje - Teisingumo ministerija $2016 \mathrm{~m}$. vasario mèn. parengè Visuomenès teisejjų (tarejų) instituto teismuose koncepciją ir pateikè ją Vyriausybei, kuri ją turètų patvirtinti atitinkamu nutarimu. Šioje koncepcijoje pateikiami svarūs argumentai tarẻjų institutui teismuose ịtvirtinti. Joje, remiantis Lietuvos teisès instituto $2015 \mathrm{~m}$. parengta monografija „Tarẻjų instituto perspek- 
tyvos Lietuvoje“, pabrèžiama, kad piliečių pasitikèjimo ir pasitenkinimo valdžia siekimas - būtinas demokratijos atributas. Šio tikslo neigyvendinus, būtina imtis institucinių arba procedūrinių reformų ar kitų adekvačių korekcinių priemonių. Viena tokių priemonių, siekiant didinti visuomenès pasitikèjimą teismų veikla, ir būtų tarẻjų instituto teismuose atsiradimas. Taigi projekto iniciatoriai eina kontinentinès teisès šalių pramintu taku ir numato tokị visuomenès įtraukimo ị teismų darbą modelị, kuris egzistuoja daugelyje valstybių, t. y. atstovavimas visuomenei priimant sprendimus per tarejjų institutą.

Tačiau kyla klausimas, ar tarejjų instituto atsiradimas tikrai yra tinkama tokių tikslų pasiekimo priemonè. Siekiant didinti visuomenès pasitikèjimą galbūt pakaktų teismų sprendimų paaiškinimo, paviešinimo, galimybės visuomenès atstovams dalyvauti teismų posėdžiuose, susipažinti su teismo posèdžio medžiaga ir pan. Svarstytina, kad galbūt visuomenès atstovams (neatmetant galimybès juos vadinti tarèjais) tikslingiau būtų suteikti galimybę paklausti, gauti paaiškinimus, tuos paaiškinimus atmesti kaip nepakankamus ir teisejjų prašyti pateikti motyvuotus paaiškinimus, į kuriuos jie turètų pareigą atsakyti, numatyti atsakomybę einant atitinkamas pareigas bei vertinimo galimybes.

Koncepcija iš tiesų pateikia gana plačią aptariamo instituto apžvalgą, nurodo teigiamus bruožus ir pateikia galimus neigiamus šios koncepcijos padarinius. Visa tai sudaro galimybes kurti gana racionalų ir optimalų tarẻjų instituto modelį. Vis dèlto šios tikrai plačios apžvalgos kontekste formuojamas gana vienapusiškas, netgi radikalus tarejjų instituto modelis, neatsižvelgiant i jau nurodytas kritines šio modelio puses, nepateikiant kompromisinio, švelnesnio tarejų instituto vaidmens teismų veikloje. Manytina, kad nepagrịstai sulyginami teisējai su tarẻjais - atitinkamą kompetenciją turintys profesionalai ir neprofesionalai, kurių pateikiami sprendimų argumentai būtų grindžiami jausmais. Teigiamas koncepcijos bruožas yra tas, kad numatoma, jog tarejjai turètų būti tam tikrų profesijų atstovai, turintys atitinkamų nagrinèjamoje byloje būtinų specialių žinių. Tačiau kyla klausimas, kur tokių specialistų (savanorių) bus galima surasti, ir kas ịvertins, kokių specialių žinių konkrečiai bylai reikia. Pastebètina, kad bylų nagrinèjimo procese, vertinant bylos aplinkybes, šiuo metu numatomas ekspertų dalyvavimas, todẻl koncepcijos modelyje numatyta visuomenès atstovų - tarèjų - specialistų atranka ir jų dalyvavimas būtų perteklinis bei vertintinas kaip daugiau problemų keliantis, nei jas sprendžiantis argumentas. Atkreiptinas dėmesys ị tai, kad tikslinga kritiškai ịvertinti patị modelị, atsižvelgiant ị koncepcijoje nurodytus tarejjų instituto pranašumus ir trūkumus. Būtina vertinti, ar tikrai tarejų instituto modelis, jo sudètiniai komponentai tarnauja tam tikslui, dèl kurio jis ir kurtas.

Lietuvos Respublikos Konstitucijos 5 straipsnyje pabrèžiama, kad valdžios ịstaigos tarnauja žmonėms, todèl turètų būti puoselèjamas kiekvienos valstybės valdžios 
institucijos (ne tik teismų) ryšys su visuomene ir kuriamos koncepcijos, kaip tai ịgyvendinti. Atsižvelgiant ị ši siekinị ir remiantis mąstymo analogija, norint aiškiau suvokti pasiūlymų esmę, galima formuluoti klausimą, ar valstybė pajègtų visuomenei už ryšį su teismais ir kitomis valdžios įstaigomis mokèti atlyginimą visose valstybès ịstaigų veiklose dalyvaujantiems visuomenès atstovams. Viena vertus, atlyginimas visuomenei yra jau tai, kad ji kontroliuoja ir pati dalyvauja priimant svarbius sprendimus. Neabejotina, kad tai yra brandžios pilietinès visuomenès ir teisinès valstybės požymis, kurị būtina puoselèti. Antra vertus, vargu ar būtų teisinga, kaip numatoma koncepcijoje, tarèjams mokèti analogišką atlyginimą kaip ir teisèjams (pagal analogiją - ir kitiems pareigūnams), nes jų atsakomybė tikrai nėra vienoda, kaip nevienoda ir kompetencija, pareigos bei, dar svarbiau, - atsakomybè ir indèlis ị bendrą darbą. Dèl šių priežasčių visuomenès atstovų darbo apmokèjimo klausimas net neturètų būti diskusijų objektas, nesvarstant argumento, ar valstybẻ būtų pajegi finansiškai pakelti šią naštą. Galbūt vietoj to būtų tikslinga didinti teisejjų padejjejų skaičių (arba darbo užmokestį, siekiant aukštesnès jų kvalifikacijos).

Koncepcijoje aiškiai nurodyti tarèjų instituto trūkumai. Be čia ịvardytų aplinkybių, būtų galima paminèti ir tai, kad kontinentinès teisès tradicijoje siūlomas tarẻjų instituto modelis galètų būti sunkiai pritaikomas. Tai apskritai keistų visą teisminę sistemą, teismo priimamų sprendimų pobūdị - nuo teisès taikymo aktų kryptume prie precedentų. Šimtmečiais mūsų šalyje vyravusi teisès tradicija patirtų mažo greitos reformos veiksmingumo pasekmes.

Manytina, kad koncepcijoje galètų būti modeliuojamas nuosaikusis modelis, kai tarèjams nebūtų mokamas atlygis ir jais galètų tapti bet kuris visuomenès atstovas, kuriam būtų suteikta procesinė teisè paklausti ir gauti motyvuotus paaiškinimus, skųsti tokių paaiškinimų nepakankamumą, kvestionuoti jų pagrịstumą, aiškumą ar pan. Toks koncepcijos modelis neformuotų intervencijos ị mūsų Konstituciją ir teisinę sistemą, o papildytų praktiką ir Konstitucijoje išreikštą siekị stiprinti valstybès valdžios institucijų ryšị su visuomene. Manytume, kad tokio siekio plètojimo modelis tikrai būtų prasmingas.

Žvelgiant retrospektyviai, visuomenès atstovavimas teismuose ir dalyvavimas priimant teisinius sprendimus Lietuvoje istoriškai nėra susiklostęs, tačiau tam tikrų visuomenès atstovų dalyvavimo vykdant teisingumą užuomazgų galima aptikti LDK laikais veikusiuose teismuose. Antai Komisarų teismas buvo susiformavęs XV a., didžiajam kunigaikščiui pradejjus skirti teisẻjus, kai bylos tyrimą reikẻdavo atlikti vietose. Tai buvo Lietuvos didžiojo teismo atšaka, sudaroma iš konkrečiai bylai skirtų asmenų nagrinèti valstybės dvarų ar jų žemių užgrobimo bei pasisavinimo bylas, taip pat spręsti ginčus dèl valstybės ir bajorų bei dvasininkijos žemių. Komisarų teismas susidejo iš trijų didžiojo kunigaikščio paskirtu ir iš tiek pat ieškovo ar atsakovo pasirinktų asmenų (Andriulis, 2002). Visuomenès atsto- 
vavimo teismuose modelis (tarèjų institutas) labiausiai buvo ịsitvirtinęs sovietinès okupacijos laikotarpiu: tarèjų institutas įtvirtintas 1940 metų LTSR Konstitucijoje ir 1978 metų LTSR Konstitucijoje. Teismo tarejų institutas įtvirtintas ir 1990 m. kovo 11 d. priimtame Lietuvos Respublikos Laikinajame pagrindiniame ịstatyme. Šiuo požiūriu čia išreikštos sovietinių konstitucijų tradicijos ir nuostatos. Laikinojo Pagrindinio ịstatymo 113 ir 115 straipsniai skelbè, kad Lietuvos Respublikos sistemą sudaro Aukščiausiasis Teismas, laikytas aukščiausiąa teismine valdžia Lietuvoje, įstatymų nustatyta tvarka vykdantis teisingumą ir prižiūrintis kitų teismų teisminę veiklą, ir rajonų (miestų) teismai. Vadovaujantis 116 straipsniu, visi teismai privalëjo būti sudaromi iš renkamų teisejų bei teismo tarejų ir bylas, išskyrus ịstatymo numatytas išimtis, nagrinèti kolegialiai. Rinkti visų grandžių teisejus, taip pat ir Aukščiausiojo Teismo tarejus, pavesta Aukščiausiajai Tarybai, o rajonų (miestų) teismų teisèjus - vietinėms Liaudies deputatų taryboms. Teisėjai turèjo būti renkami dešimčiai metų, tarẻjai - penkeriems. Tęsiant sovietinès teisinès sistemos tradicijas, nepriklausomoje Lietuvos Respublikoje teismų tarejjų institutas, įtvirtintas konstituciniu lygmeniu, dar gyvavo beveik trejus metus. Prieš pat Lietuvos Nepriklausomybès Akto paskelbimą - 1990 m. vasario 13 d. paskelbtame ir iki 1995 m. sausio 1 d. galiojusiame SSR Teismų santvarkos ir teisejjų statuso ịstatyme palikta gyvuoti ne tik teismo tarejų, bet ir ịvesta nauja - prisiekusiujų teismo institucija; 9 straipsnio 4 punktas skelbè, kad baudžiamąsias bylas dèl padarytų nusikaltimų, už kuriuos įstatyme numatyta mirties bausmè, nagrinèja prisiekusiujjų teismas. Tačiau reformuojant teismų sistemą atsisakyta tiek teismo tarejų, tiek prisiekusiujų teismo instituto.

Praèjus dvidešimt penkeriems metams po minètų institutų panaikinimo, vėl grižtama prie diskusijų, ar veiksminga būtų steigti prisiekusiųų teismą ir teismo tarejų institutą. Turint omenyje tai, kad teismų sistema labai nepasitikima, svarbu atsakyti ị klausimą, ar Lietuva turi sekti kitų demokratinių šalių, kurios leidžia savo piliečiams dalyvauti vykdant teisingumą, pavyzdžiu. Siekiant pateikti išvadas dẻl tikslingumo Lietuvos Respublikos teismų sistemoje ịvesti tarèjų institutą, taip galimai priartinant visuomenès dalyvavimą, tikslinga bent trumpai apžvelgti užsienio šalių patirti šioje srityje.

Lietuvos Respublikos Seimo kanceliarijos Parlamentinių tyrimų departamento atliktame tyrime ${ }^{1}$ konstatuojama, kad teismo tarejų institutas egzistuoja Austrijoje, Belgijoje, Bulgarijoje, Čekijoje, Danijoje, Estijoje, Ispanijoje, Jungtinėje Karalysteje, Lenkijoje, Maltoje, Portugalijoje, Prancūzijoje, Slovakijoje, Slovenijoje, Suomijoje, Švedijoje, Vengrijoje, Vokietijoje, Šveicarijoje, Ukrainoje. 2009 m. tarejų instituto atsisakyta Latvijoje, kur jie dalyvavo nagrinėjant baudžiamąsias bylas. Slo-

1 Teismo tarèjų ir prisiekusiųų institutas Europos Sajungos ir kitose užsienio valstybèse, 2011-02-01. 
vėnijoje $2010 \mathrm{~m}$. atsisakyta tarejų dalyvavimo civilinėse bylose, 2003-2004 m. atsisakyta Rusijoje, kur jie dalyvavo baudžiamosiose ir civilinėse bylose. Kai kuriose šalyse (Belgijoje, Jungtinèje Karalystėje, Prancūzijoje) tarèjai panašesni ị neprofesionalius, bet beveik nuolat veikiančius teisëjus ịvairiuose bendrosios kompetencijos ar specializuotuose teismuose, kuriuose tam tikras bylas jie nagrinejja nedalyvaujant profesionaliems teisejjams. Šveicarijoje pirmosios instancijos teismo teisejjai renkami iš kandidatų, kuriais gali būti visi rinkimų teisę turintys piliečiai, nepaisant jų išsilavinimo (teisinis išsilavinimas būtinas tik teismų pirmininkams). Prisiekusiujų tarējų (ar prisiekusiujų teismo, žiuri) institutas egzistuoja Austrijoje, Danijoje, Ispanijoje, Jungtinëje Karalysteje, Maltoje, Portugalijoje, Prancūzijoje, tam tikrose specifinėse bylose - Švedijoje. Jis yra ir JAV bei Rusijoje. Pastaraisiais metais prisiekusiuju teismo atsisakyta Šveicarijoje. Ukrainoje prisiekusiujų teismą numato Konstitucija ir teismų ịstatymas, tačiau praktikoje šis institutas neveikia. Jau aptartoje Teisingumo ministerijos parengtoje Visuomeninių teisejjų (tarejų̧) instituto teismuose koncepcijoje aptarti trys pagrindiniai visuomenès dalyvavimo vykdant teisingumą modeliai: prisiekusiujų teismas, tarėjų institutas ir taikos teisèjai. Konstatuojama, kad plačiausiai Europoje paplitęs vokiškasis tarèjų modelis, kurio esmè ta, kad teisejjai ir tarejai bylas nagrinejja mišriose kolegijose ir turi vienodą teisę priimant sprendimus. Klasikinę kolegiją šiuo atveju sudaro vienas profesionalus teisejjas ir du tarejjai, tačiau tai nèra visuotinai priimta taisyklè, nes teismo sudètis skirtingo pobūdžio bylose gali būti ir kita. Esminè taisyklè - tarèjų skaičius profesionalių teisejų skaičių turi viršyti ne daugiau kaip vienu. Šiuo metu tarèjų dalyvavimas numatytas daugelyje baudžiamųjų bylų, išskyrus bylas dẻl sunkių politinių nusikaltimų. Be to, išimtis nustatyta ir smulkiems baudžiamiesiems nusižengimams, kuriuos vienasmeniškai nagrinèja profesionalus tarejas. Paminėtina, kad Vokietijoje tarejjai dalyvauja ir spręsdami administracines, darbo, prekybos, žemès ūkio, socialinès gerovès, mokesčiu bei kitas bylas. Apibendrintai galima teigti, kad teismų darbe visuomenè (neprofesionalai) dalyvauja visose Vakarų Europos šalyse (vienintele išimtis - Nyderlandai), o apskritai pasaulyje labiausiai paplitęs vokiškasis, vadinamasis Schöffen modelis ${ }^{2}$ (Ragauskas, 2015).

Grịžtant prie Lietuvos atvejo, pastebėtina, kad ịdiegus tarẻjų institutą Lietuvoje galimos tiek teigiamos, tiek ir neigiamos pasekmès. Jau minètoje Teisingumo ministerijos parengtoje koncepcijoje nurodomos tokios teigiamos pasekmès: visuomenès švietimas, požiūriu ịvairovè, ,gyvosios“ ir formaliosios teisès suartinimas, didesnis demokratiškumas, papildoma apsauga nuo galimo poveikio teismui ir paties teismo piktnaudžiavimo, papildomas teisejjų nepriklausomumo garantas, didesnis legitimumas. İžvelgiamos ir tokios neigiamos pasekmès: išaugusios sąnaudos, sprendimų pagrindimas teisingumo jausmu, emocijomis, prietarais ir stereo-

2 Prieiga internete: www.schoeffen.de 
tipais, tarèjų korupcijos bei šališkumo rizika, grèsmè jurisprudencijos tęstinumo principui, neprognozuojami sprendimai, išaugęs kvalifikuoto teisinio atstovavimo poreikis, grèsmè tarėjams dẻl atliekamų funkcijų pobūdžio.

Vis dèlto tarẻjų įtraukimas ị tam tikrų kategorijų bylas, ypač kuriose kaip viena iš šalių dalyvauja valstybės valdžios institucijų atstovai, išsklaidytų nemažai abejonių priimant teismo sprendimą. Taip teismas, kurio sprendimų prièmimo procese dalyvautų ir piliečiai, būtų labiau nepriklausomas nuo nepageidaujamos išorinès ịtakos. Be to, tokiuose sprendimuose atsiskleistų ir bendražmogiškas požiūris ị teisingumą, didesnis dèmesys būtų kreipiamas ị visuomenès ginamas vertybes, nes priimant sprendimus dalyvautų ne tik teisés specialistai. Savaime suprantama, viena iš tarẻjų institucijos steigimo kliūčių - ne tik teisiniai sprendimai, bet ir valstybès finansinès galimybès.

Aptarus teisminès valdžios atvirumo visuomenei problemas, darytina išvada, kad Lietuvoje vis didesnę reikšmę teisèjų skyrimo, vertinimo, kontrolès procese igyja visuomenės atstovai. Lietuva - viena iš nedaugelio demokratiškų valstybių, neturinti prisiekusiųjų teismo ar tarejjų instituto, kurio ịsteigimas padètų mažinti korupciją teisinėje sistemoje, būtų žengtas žingsnis didinant visuomenès pasitikèjimą teismine valdžia. Be to, teismo viešumo didinimas gali išspręsti teisejjų atskaitomybès visuomenei problemą.

Galime sutikti su nuomone, kad tarejų instituto privalumas yra tas, kad visuomenès atstovų dalyvavimas vykdant teisingumą didina piliečiu pasitikèjimą teismais ir teisingumu, teismas tampa atviresnis visuomenei. Tarejų institutas neleidžia formuotis uždarai, biurokratiškai ir rutiniškai teisejjų kastai. O tai, be abejo, svarūs argumentai, igyvendinant Lietuvos Respublikos Konstitucijos preambulèje įtvirtintą teisinès valstybès siekį.

\section{Išvados}

1. Teismas yra viena iš valstybès valdžios sudètinių dalių, kuris išimtinai kompetentingas vykdyti teisingumą. Ypatingą vietą teismai užima ir visuomenès sąmonèje, nes lieka vienintele viltimi ginant pažeistas teises bei laisves.

2. Šiuolaikiniai visuomenès ir valstybės valdžios institucijų santykiai vertinami pasitikèjimo lygiu, kuris savo ruožtu yra visuomenės saugumo pojūčio ir gerovès kūrimo pagrindas. Pasitikèjimas teismais - tai žmonių tikèjimas, kad sąžiningai ir atsakingai bus įgyvendintas teisingumas, kaip žmogaus teisių ir laisvių apsaugos šaltinis. Teismas yra vienas iš socialinès darnos irankių, todèl visuomenei svarbu žinoti, kad bet kuriuo atveju bus užtikrintos piliečio teisès bei laisvès ir bet koks kilęs ginčas bus išspręstas teisin- 
gai ir nešališkai. Pasitikèjimas teismais būtinas, siekiant, kad veiksmingai funkcionuotų demokratinè teisinè valstybė ir būtų formuojama pilietinė visuomenè, kuri būtų garantuota, jog jos pažeistos teisès ir laisvès visada bus apgintos nepriklausomo ir nešališko teismo.

3. Pagrindiniai veiksniai, darantys ịtaką pasitikejjimui teismais, yra: teismų nepriklausomumas, jų sprendimų veiksmingumas ir pagarba jiems, aukšta teisejo kvalifikacija, moralè, teismo veiklos viešumas, teismo procesas, procesinè teisèjo elgsena, teismų veiklos administravimo veiksmingumas. Pasitikèjimas teismais susijęs ir su socialinio pasitikèjimo bei teisės būkle apskritai. Kaip pagrindą teisingai ir pagristai nuomonei apie teismus formuotis reikia įvardyti nuoseklų visuomenès teisinès sąmonès formavimą, kuriai pastaruoju metu didžiausią įtaką daro žiniasklaidos pateikiama informacija. Vienas pagrindinių pasitikejjimo teismais veiksnių yra teismų ir teisėjų nepriklausomumas, kuris yra teismų institucijos stabilumo garantas. Teismų nepriklausomumas demokratinèje valstybeje yra pareiga ir viena svarbiausių sąlygų, norint apginti žmogaus teises bei laisves. Tai pareiga vadovaujantis įstatymų reikalavimais ir teisingumo supratimu, nepaisant visokios galimos įtakos iš šalies, spręsti konkrečią bylą, taip tampant visuomeninių ir ekonominių santykių stabilumo garantu.

4. Konstitucijoje ịtvirtinta teismų instancinè sistema sudaro galimybes šalinti galimas žemesnių instancijų teismų klaidas, neleisti, kad būtų ịvykdytas neteisingumas, šitaip apsaugomos asmens, visuomenès teisès ir teisèti interesai. Tokia klaidų ištaisymo galimybė yra viena iš visuomenès pasitikejjimo visa bendrosios kompetencijos teismų sistema garantijų.

5. Pagrindinès teismų veiklos problemos - teisejjų darbo krūvis, proceso koncentracija ir ekonomiškumas, teismų finansavimas, teismo proceso modernizavimas. Dažnai besikeičiantys įstatymai, reguliuojantys teismų veiklos klausimus, rodo valstybės pastangas užtikrinti veiksmingą teismo funkcijų igyvendinimą. Informacinès technologijos palengvina teismų organizacini darbą, leidžia lètai, bet spręsti pagrindinę - teisèjų darbo krūvio problemą.

6. Pasitikejjimas teismais auga, kai bylų nagrinèjimas atitinka procedūrinio teisingumo reikalavimus, tokius kaip galimybe išsakyti požiūrị, išaiškinti šalims apskundimo galimybes ir teisèjo etiką. Kadangi bylos nagrinèjimo procedūrai vadovauja teisèjas, svarbi yra jo kvalifikacija ir elgesys teismo proceso metu.

7. Lietuvos Respublikos Konstitucijos 5 straipsnyje pabrèžiama, kad valdžios ịstaigos tarnauja žmonèms, todèl turètų būti puoselëjamas visų valstybės valdžios institucijų (ne tik teismų) ryšys su visuomene ir kuriamos koncepcijos, kaip tai igyvendinti. İdomus būtų visų kitų valdžios ịstaigų (visuo- 
menès pasitikèjimas kuriomis taip pat yra žemas) atsakomybės visuomenei modelis.

8. Visuomenès ir valdžios santykis grindžiamas visuomeniniais pagrindais. Todèl visuomenès atstovų darbo apmokejimo klausimas net neturètų būti diskusijų objektu. Skatintinos diskusijos apie nuosaikuji tarejų instituto modelį, kuris koncepcijose net nemodeliuojamas: taikant šį modelị tarèjai dirbtų neatlygintinai ir jais galètų būti bet kuris visuomenès atstovas, turintis procesinę teisę paklausti ir gauti motyvuotus teismo paaiškinimus, skųsti tokių paaiškinimų nepakankamumą, kvestionuoti jų pagrịstumą, aišskumą ir pan. Toks koncepcijos modelis neformuotų intervencijos ị mūsų Konstituciją ir teisinę sistemą, tik papildytų praktiką bei Konstitucijoje išreikštą siekị stiprinti valstybès valdžios institucijų ryši su visuomene. Jis tikrai būtų prasmingas ir labai reikalingas.

\section{Literatūra}

Abramavičius, A. (2009). Teisè ị teisminę gynybą Lietuvos Respublikos Konstitucinio Teismo jurisprudencijoje. Jurisprudencija 3(117): 21-40.

Andriulis, V. (2002). Lietuvos teisès istorija. Vilnius: Justitia, p. 159-169.

Baublys, L. (2005). Antikine teisingumo samprata ir jos įtaka Vakaru teisés tradicijai. Vilnius: Mykolo Romerio universitetas, p. 7.

Beinoravičius, D. (2013). Žmogaus teisiu apsangos problemos teismams vykdant teisinguma. Konstitucionalizmas ir teisès politika Europos Sajungoje. Mokslo studija. Vilnius: Mykolo Romerio universitetas, p. 246.

Bilevičiūtè, E. (2014). Pirminès teisinès pagalbos koncepcija ir jos igyvendinimo probleminiai aspektai. Asmens teisiu gynimas: problemos ir sprendimai: 553-585. Mokslo studija. Vilnius: Mykolo Romerio universitetas.

Birmontienè, T. (2012). Lietuvos konstitucinè teisè. Vadovèlis. Vilnius: Mykolo Romerio universitetas, p. 683 .

Burnytè, M. (2013). Pasitikèjimas politinèmis ir teisèsaugos institucijomis Lietuvoje. Teisès problemos 4: 82 .

Ragauskas, P. (2015). Tarejjų instituto perspektyvos Lietuvoje. Monografija. Vilnius: Lietuvos teisès institutas, p. 91-131.

Valančius, V.(2005). Pasitikejjimas teismu: kai kurie teismo veiklos viešumo aspektai. Jurisprudencija 78(70): 86. 


\section{THEORETICAL ASPECTS MODELLING THE INSTITUTE OF ASSES- SORS IN THE JUDICIARY OF THE REPUBLIC OF LITHUANIA}

\section{Darijus Beinoravičius, Milda Vainiutė}

Summary

The court is one of the constituent parts of state power, which has exclusive jurisdiction to pursue justice. The courts also play a special role in the public consciousness, because the courts remain the only hope in protecting violated rights and freedoms.

Modern relations between society and state authorities are valued at the level of trust, which in turn is the basis for creating a sense of public security and wellbeing. Trust in courts is a people's faith in the implementation of honest and responsible justice as a source of protection of human rights and freedoms. The court is one of the tools of social harmony, therefore it is important for the public to know that in any case the rights and freedoms of the citizens will be ensured, that any disputes will be solved fairly and impartially. Trust in the courts is necessary for the effective functioning of a democratic state under the rule of law and for the creation of a civil society which guarantees that the violated rights and freedoms will always be protected by an independent and impartial court.

The main factors influencing trust in the courts are: independence of the courts, efficiency of court decisions and respect for them, high qualification and morale of the judge, publicity of court activity, court process, procedural behaviour of the judge, efficiency of administration of court activity. Trust in courts is also based on the social trust and condition of law in general. As a basis for the formation of a fair and reasonable opinion concerning courts, it is necessary to refer to the consistent formation of the legal consciousness of the society, which has been most influenced by media information in recent times. One of the most important factors in trust the courts is the independence of the courts and judges, which is the guarantee of stability of the judiciary. The independence of the judiciary in a democratic state is a duty and one of the most important conditions for the protection of human rights and freedoms. It is a duty, in accordance with the requirements of the law and the understanding of justice, to judge a particular case, independently of any possible influence from the side, thus becoming a guarantor of the stability of social and economic relations.

The settled in Constitution system of the courts establishes the possibilities for eliminating possible mistakes of the courts of lower instances, preventing injustice, thus protecting the rights of a person, society and legitimate interests. Such a remedy is one of the guarantors of public confidence in the whole system of general jurisdiction. 
The main problems of court activity are the workload of judges, the concentration and economy of procedures, the financing of courts, and the modernization of court proceedings. Frequently changing laws regulating court activity issues indicate the state's efforts to ensure the effective implementation of court functions. With the help of information technology, the organizational work of courts is facilitated, but slowly, thus the main problem - the workload of judges - is being solved.

Trust in courts is growing when the hearing of cases complies with the requirements of procedural justice, such as the possibility of expressing a view, the clarification of appeals to the parties and the ethics of the judge. As the proceedings are conducted by a judge, the qualification of the judge and the behaviour of the judge during the trial are very important. Article 5 of the Constitution of the Republic of Lithuania emphasizes that public authorities serve people, and therefore the relationship of state public authorities (not just of courts) with the public should be developed and concepts developed for their implementation. It would be interesting to have a model of public accountability for all other government bodies (which also have low public confidence).

There is a constant debate among lawyers and scientists about the Institute of Jury or Assessors. However, most lawyers are cautious about the effectiveness and expediency of these institute. Some consider it as one of the means of transparent judicial power, the means of ensuring the transparency of the judiciary, thus reducing the doubts about the objectivity of judgments made and increasing trust in the courts; others consider that our society has not yet become accustomed to such changes, the more the society itself does not express a strong need. True, Seimas (Lithuania Parliament) should change the Constitution. Thus, the most important problem of the establishment of the Institute of Assessors is connected with the Constitution, in Section IX "The Court", which establishes the structure of the courts of the Republic of Lithuania and the principles of activity, the mandatory provision stipulating that judges are appointed (Article 112), provides for the possibility of setting up specialized courts only. The issue of the Institute of Assessors in courts, or at least the prospect of establishing it, is not discussed here. In order to consolidate this institute, it would undoubtedly be necessary to amend the Constitution.

The public is engaged in public relations with public authorities. For these reasons, the issue of compensation to the public representatives should not even be the subject of debate. The debate about the modest model of the Institute of Assessors, according to which the assessors would work gratis and would be any representatives of the society, having the procedural rights to ask and receive motivated court explanations, complain about the lack of such explanations, questioning their validity, clarity, etc. which is not even modelled in the concepts, is encouraged. 
Such a model of conception would not form an intervention in our Constitution and the legal system, but would complement the practice and the desire expressed in the Constitution to strengthen the relationship between the state authorities and the public. A model for developing this endeavour would certainly be meaningful and very necessary. 
